\title{
DNA Similarities among Mosquito-Pathogenic and Nonpathogenic Strains of Bacillus sphaericus
}

\author{
KAREN E. RIPPERE, ${ }^{1}$ JOHN L. JOHNSON, ${ }^{2}$ AND ALLAN A. YOUSTEN ${ }^{1 *}$ \\ Microbiology Section, Biology Department, ${ }^{1}$ and Department of Anaerobic Microbiology, ${ }^{2}$ \\ Virginia Polytechnic Institute and State University, Blacksburg, Virginia 24061
}

\begin{abstract}
Bacillus sphaericus strains isolated on the basis of pathogenicity for mosquito larvae and strains isolated on the basis of a reaction with a $B$. sphaericus DNA homology group IIA 16S rRNA probe were analyzed for DNA similarity. All of the pathogens belonged to homology group IIA, but this group also contained nonpathogens. It appears inappropriate to designate this homology group a species based solely upon pathogenicity.
\end{abstract}

Aerobic bacilli that form spherical endospores are common in soil and water and are usually classified as Bacillus sphaericus. There are few useful phenotypic tests for identification of these bacteria. Spore morphology combined with negative reactions in tests for fermentation products and extracellular enzymes have been the basis for taxonomic placement. The species was found to be comprised of at least five distinct homology groups, each sufficiently separated from the others to merit species status (5). Representative strains of the homology groups have also been examined by rRNA gene restriction fragment length polymorphisms analyses (ribotyping), and these analyses confirmed that there are distinct groups within the B. sphaericus complex (2). Recently, randomly amplified polymorphic DNA analysis has also clearly distinguished the groups originally identified by DNA similarity analysis (9). These five groups have not been designated separate species because of the lack of readily utilizable phenotypic tests to distinguish them.

In the original study of Krych et al. (5), group II was divided into two subgroups based on levels of DNA similarity and DNA heteroduplex stability. It was of considerable interest that all of the isolates in group IIA were pathogenic for mosquito larvae. No mosquito pathogens were found in any other group. These bacteria are pathogenic because they produce one or more of four toxins, a binary toxin composed of two distinct proteins and three additional toxins designated Mtx, Mtx2, and Mtx3 (6-8). Strains that produce the binary toxin are highly toxic $\left(50 \%\right.$ lethal concentrations, around $10^{2}$ to $10^{3}$ cells $\mathrm{ml}^{-1}$ ), and strains that produce only toxins Mtx, Mtx2, and Mtx3 have low toxicity (50\% lethal concentrations, about $10^{5}$ to $10^{7}$ cells $\mathrm{ml}^{-1}$ ). It appeared that the group IIA mosquito pathogens might be designated a separate species. However, only seven pathogenic isolates were available at the time of the original DNA similarity study. Now, many more pathogenic isolates from many geographic locations are available, and although they have been referred to as group IIA strains on the basis of ribotyping data, DNA similarity studies have never actually been performed with them. In this paper we report DNA similarity results for a large number of strains from diverse geographic locations.

Bacteria and DNA isolation. The strains of $B$. sphaericus used in this study are listed in Table 1 . The bacteria were grown in NY broth (Difco nutrient broth supplemented with $0.05 \%$ yeast extract) at $30^{\circ} \mathrm{C}$ with shaking at $150 \mathrm{rpm}$. Cells were recovered by centrifugation, suspended in $20 \mathrm{ml}$ of $\mathrm{pH} 8.0$ buffer (10 mM Tris, $1.0 \mathrm{mM}$ EDTA, $0.35 \mathrm{M}$ sucrose, $0.1 \mathrm{mg}$ of

\footnotetext{
* Corresponding author. E-mail: Yousten@vt.edu.
}

TABLE 1. Strains used in this study

\begin{tabular}{|c|c|c|c|}
\hline Strain & Source & Geographic origin & Serotype \\
\hline $\begin{array}{l}\mathrm{ATCC} \\
14577^{\mathrm{T} a}\end{array}$ & $-^{b}$ & $\mathrm{NA}^{c}$ & NA \\
\hline $1593^{d}$ & - & Indonesia & $5 \mathrm{a} 5 \mathrm{~b}$ \\
\hline ATCC 7055 & - & NA & NA \\
\hline NRS 592 & - & NA & NA \\
\hline NRS 400 & - & NA & NA \\
\hline NRS 1198 & - & NA & NA \\
\hline Kellen $\mathrm{Q}^{d}$ & - & United States & $1 \mathrm{a}$ \\
\hline SSII- $1^{d}$ & - & India & $2 a 2 b$ \\
\hline $1404^{d}$ & - & The Philippines & $2 a 2 b$ \\
\hline $1881^{d}$ & - & El Salvador & $5 a 5 b$ \\
\hline $1691^{d}$ & - & El Salvador & $5 a 5 b$ \\
\hline $1885^{d}$ & Singer & Israel & $2 \mathrm{a} 2 \mathrm{~b}$ \\
\hline $\mathrm{LP}^{2}-\mathrm{AS}^{d}$ & Priest & Singapore & 3 \\
\hline LP1-G ${ }^{d}$ & Priest & Singapore & 3 \\
\hline LP7-A ${ }^{d}$ & Priest & Singapore & 3 \\
\hline IAB $881^{d}$ & Ofori & Ghana & 3 \\
\hline $2362^{d}$ & Weiser & Nigeria & $5 \mathrm{a} 5 \mathrm{~b}$ \\
\hline BSE1 $8^{d}$ & Priest & Scotland & $5 \mathrm{a} 5 \mathrm{~b}$ \\
\hline $2013-6^{d}$ & Singer & Romania & $5 a 5 b$ \\
\hline $2317-3^{d}$ & Singer & Thailand & $5 \mathrm{a} 5 \mathrm{~b}$ \\
\hline $2500^{d}$ & Singer & Thailand & $5 a 5 b$ \\
\hline TS- $1^{d}$ & Gaixin & $\begin{array}{l}\text { People's Republic of } \\
\text { China }\end{array}$ & $5 \mathrm{a} 5 \mathrm{~b}$ \\
\hline $\mathrm{JI} 21^{d}$ & Ibarra & Mexico & $5 \mathrm{a} 5 \mathrm{~b}$ \\
\hline $\mathrm{JI} 42^{d}$ & Ibarra & Mexico & $5 \mathrm{a} 5 \mathrm{~b}$ \\
\hline $2117-2^{d}$ & Singer & The Philippines & $5 a 5 b$ \\
\hline $\mathrm{RS} \mathrm{A}^{d}$ & deSouza & Brazil & NA \\
\hline $\mathrm{RS} 2 \mathrm{~A}^{d}$ & deSouza & Brazil & NA \\
\hline $\mathrm{S} 2^{d}$ & Vilarinhos & Brazil & $5 a 5 b$ \\
\hline${\mathrm{TG} 148^{d}}$ & Guaycurus & Brazil & $5 \mathrm{a} 5 \mathrm{~b}$ \\
\hline TG229d & Guaycurus & Brazil & $5 \mathrm{a} 5 \mathrm{~b}$ \\
\hline $\mathrm{CIB} 14^{d}$ & Orduz-Peralta & Nigeria & NA \\
\hline IAB59 $9^{d}$ & Ofori & Ghana & 6 \\
\hline $\mathrm{IAB} 460^{d}$ & Ofori & Ghana & 6 \\
\hline $\mathrm{IAB} 871^{d}$ & Ofori & Ghana & 6 \\
\hline $31-2^{d}$ & Cokmus & Turkey & $9 a 9 c$ \\
\hline $2297^{d}$ & Wickremsinghe & Sri Lanka & 25 \\
\hline TG365 & Guaycurus & Brazil & 25 \\
\hline $2173^{d}$ & Amonkar & India & $26 \mathrm{a} 26 \mathrm{~b}$ \\
\hline $2377^{d}$ & Amonkar & India & $26 a 26 b$ \\
\hline G4a & Priest & Brazil & NA \\
\hline Gt1-a & Priest & Brazil & 6 \\
\hline Gt1-d & Priest & Brazil & 2 \\
\hline R1e & Priest & Brazil & 6 \\
\hline R4a & Priest & Brazil & $26 a 26 b$ \\
\hline
\end{tabular}


TABLE 2. Levels of DNA similarity among strains of B. sphaericus

\begin{tabular}{|c|c|c|c|c|c|c|c|}
\hline \multirow{2}{*}{ Unlabeled strain } & \multicolumn{7}{|c|}{$\%$ Similarity with: } \\
\hline & $\begin{array}{l}\text { Group I strain } \\
\text { ATCC } 14577^{\mathrm{T}}\end{array}$ & $\begin{array}{l}\text { Group IIa strain } \\
1593\end{array}$ & $\begin{array}{l}\text { Group IIb strain } \\
\text { ATCC } 7055\end{array}$ & $\begin{array}{l}\text { Group III strain } \\
\text { NRS } 592\end{array}$ & $\begin{array}{l}\text { Group IV strain } \\
\text { NRS } 400\end{array}$ & $\begin{array}{l}\text { Group V strain } \\
\text { NRS } 1198\end{array}$ & $\begin{array}{l}\text { Strain } \\
\text { Gt1-a }\end{array}$ \\
\hline ATCC $14577^{\mathrm{T}}$ & 100 & 26 & 27 & 26 & 28 & 29 & 26 \\
\hline 1593 & 26 & 100 & 71 & 45 & 41 & 29 & 90 \\
\hline ATCC 7055 & 26 & 74 & 100 & 54 & 46 & 31 & 75 \\
\hline NRS 592 & 28 & 46 & 43 & 100 & 53 & 30 & 46 \\
\hline NRS 400 & 28 & 47 & 44 & 32 & 100 & 33 & 50 \\
\hline NRS 1198 & 29 & 31 & 28 & 57 & 31 & 100 & 52 \\
\hline Kellen Q & 26 & 91 & 69 & 48 & 43 & 30 & 90 \\
\hline SSII-1 & 27 & 93 & 72 & 45 & 43 & 30 & 91 \\
\hline 1404 & 26 & 91 & 71 & 45 & 43 & 30 & 90 \\
\hline 1881 & 26 & 100 & 71 & 46 & 44 & 30 & 93 \\
\hline 1691 & 32 & 98 & 69 & 44 & 45 & 30 & 92 \\
\hline 1885 & 31 & 91 & 73 & 46 & 44 & 29 & 91 \\
\hline LP12-AS & 27 & 92 & 76 & 46 & 43 & 30 & 91 \\
\hline LP1-G & 31 & 88 & 68 & 48 & 45 & 30 & 92 \\
\hline LP7-A & 26 & 93 & 71 & 47 & 45 & 30 & 90 \\
\hline IAB 881 & 26 & 90 & 70 & 47 & 40 & 30 & 89 \\
\hline 2362 & 33 & 98 & 70 & 45 & 45 & 30 & 90 \\
\hline BSE 18 & 33 & 99 & 66 & 45 & 41 & 30 & 89 \\
\hline 2013-6 & 26 & 99 & 71 & 46 & 44 & 30 & 93 \\
\hline $2317-3$ & 26 & 100 & 69 & 46 & 41 & 30 & 89 \\
\hline 2500 & 27 & 100 & 71 & 47 & 44 & 30 & 92 \\
\hline Ts-1 & 26 & 93 & 69 & 47 & 43 & 29 & 90 \\
\hline JI 21 & 31 & 98 & 70 & 45 & 43 & 30 & 89 \\
\hline JI 42 & 27 & 98 & 70 & 46 & 43 & 30 & 85 \\
\hline $2117-2$ & 26 & 98 & 71 & 48 & 43 & 30 & 92 \\
\hline RS1A & 31 & 99 & 72 & 47 & 43 & 30 & 92 \\
\hline RS2A & 26 & 98 & 68 & 45 & 43 & 29 & 90 \\
\hline $\mathrm{S} 2$ & 25 & 95 & 66 & 48 & 39 & 29 & 88 \\
\hline TG 148 & 26 & 100 & 70 & 48 & 44 & 29 & 91 \\
\hline TG 299 & 26 & 97 & 71 & 43 & 42 & 30 & 92 \\
\hline CIB NIG 14 & 33 & 98 & 71 & 47 & 43 & 30 & 93 \\
\hline IAB 59 & 27 & 91 & 70 & 48 & 43 & 29 & 90 \\
\hline IAB 460 & 26 & 84 & 70 & 45 & 40 & 30 & 89 \\
\hline IAB 871 & 26 & 93 & 70 & 46 & 42 & 30 & 92 \\
\hline $31-2$ & 26 & 90 & 69 & 47 & 43 & 29 & 88 \\
\hline 2297 & 30 & 89 & 70 & 47 & 44 & 29 & 88 \\
\hline TG 365 & 29 & 93 & 69 & 47 & 44 & 31 & 90 \\
\hline 2173 & 27 & 91 & 72 & 45 & 45 & 28 & 92 \\
\hline 2377 & 27 & 91 & 68 & 45 & 44 & 31 & 89 \\
\hline G4a & 63 & 91 & 73 & 51 & 46 & 33 & 91 \\
\hline Gt1-a & 27 & 90 & 71 & 47 & 44 & 32 & 100 \\
\hline Gt1-d & 28 & 92 & 72 & 47 & 42 & 30 & 91 \\
\hline R1e & 26 & 90 & 71 & 48 & 42 & 29 & 92 \\
\hline R4a & 26 & 89 & 70 & 42 & 41 & 30 & 89 \\
\hline
\end{tabular}

lysozyme per $\mathrm{ml}$ ), and incubated at $37^{\circ} \mathrm{C}$ for $30 \mathrm{~min}$. A $20-\mathrm{ml}$ portion of lysing solution (100 mM Tris, $20 \mathrm{mM}$ EDTA, $0.3 \mathrm{M}$ $\mathrm{NaCl}, 2 \%$ [wt/vol] sodium dodecyl sulfate, $2 \%$ [vol/vol] $\beta$-mercaptoethanol, $100 \mu \mathrm{g}$ of proteinase $\mathrm{K}$ per $\mathrm{ml}$ ) was added to each preparation, and the mixture was incubated at $55^{\circ} \mathrm{C}$ for $1 \mathrm{~h}$. Protein was removed by multiple phenol-chloroform extractions, and DNA was precipitated with 0.6 volume of isopropanol. The DNA was dried and suspended in $20 \mathrm{ml}$ of TE, $250 \mu \mathrm{l}$ of an RNase solution (1 mg of RNase A per ml, 4,000 $\mathrm{U}$ of RNase $\mathrm{T}_{1}$ per $\mathrm{ml}$ ) was added, and the preparation was incubated $1 \mathrm{~h}$ at $37^{\circ} \mathrm{C}$. The DNA was chloroform extracted and precipitated with ethanol. The precipitated DNA was dissolved in $3 \mathrm{ml}$ of TE and frozen.

DNA homologies. DNA was sheared in a French pressure cell and labeled with ${ }^{125} \mathrm{I}$, and a hybridization analysis was performed by using the $S 1$ nuclease method (4). DNA samples were heated for $5 \mathrm{~min}$ at $60^{\circ} \mathrm{C}$ before they were used. Reaction tubes containing $10 \mu \mathrm{l}$ of labeled DNA $(0.4 \mathrm{mg} / \mathrm{ml}), 50 \mu \mathrm{l}$ of unlabeled DNA $(0.4 \mathrm{mg} / \mathrm{ml})$, and $50 \mu \mathrm{l}$ of buffer $(13.2 \times \mathrm{SSC}$, $5 \mathrm{mM}$ HEPES; pH $7.0[1 \times \mathrm{SSC}$ is $0.15 \mathrm{M} \mathrm{NaCl}$ plus $0.015 \mathrm{M}$ sodium citrate]) were incubated at $60^{\circ} \mathrm{C}$ for $24 \mathrm{~h}$ to allow reassociation. Following this incubation, $1 \mathrm{ml}$ of buffer $(0.3 \mathrm{M}$ $\mathrm{NaCl}, 0.05 \mathrm{M}$ acetic acid, $0.5 \mathrm{mM} \mathrm{ZnCl}_{2}$ ), $100 \mathrm{U}$ of S1 nuclease, and $50 \mu \mathrm{l}$ of denatured salmon sperm DNA $(0.4 \mathrm{mg} / \mathrm{ml})$ were added to each reaction mixture, and the mixture was incubated for $1 \mathrm{~h}$ at $50^{\circ} \mathrm{C}$. Then $0.5 \mathrm{ml}$ of $\mathrm{HCl}$ buffer $(1 \mathrm{M} \mathrm{HCl}$, $\left.1 \% \mathrm{Na}_{4} \mathrm{P}_{2} \mathrm{O}_{7}, 1 \% \mathrm{NaH}_{2} \mathrm{PO}_{4}\right)$ and $50 \mu \mathrm{l}$ of native salmon sperm DNA $(1.2 \mathrm{mg} / \mathrm{ml})$ were added to the reaction mixture, and the preparation was incubated for $1 \mathrm{~h}$ at $4^{\circ} \mathrm{C}$ to precipitate the DNA. The precipitated DNA was collected on Whatman glass fiber filters and counted with a gamma counter.

The strains used as reference strains for the homology groups were the same as those used in the study of Krych et al. (5). An additional strain, strain Gt1-a, was labeled and also used as a reference. Also, six of the seven pathogenic strains included in group IIA in the original study were analyzed 
again. A total of 27 additional mosquito pathogens from a variety of geographic locations were included in the study. These pathogens had been isolated on the basis of their ability to kill mosquito larvae. Each of these isolates, regardless of its level of toxicity, was found to be a member of homology group IIA (Table 2). This suggests that the four genes that have been identified as being responsible for toxicity in these bacteria have not been transferred beyond this genetically defined group. As long as isolations were made on the basis of mosquito pathogenicity, it appeared that homology group IIA might contain only these distinctive pathogenic bacteria.

Jahnz et al. (3) utilized an oligonucleotide probe based on a specific region of $16 \mathrm{~S}$ rRNA from group IIA strains (1) to isolate group IIA strains not on the basis of pathogenicity but on the basis of membership in homology group IIA. These authors recovered 20 strains from Brazilian soil that produced ribotype and isozyme patterns typical of group IIA. However, these strains lacked mosquito pathogenicity, and probes for the binary toxin and Mtx toxin revealed that the genes for these toxins were absent. We included five of these strains in this study (strains G4a, Gt1-a, Gt1-d, R1e, and R4a) and utilized Gt1-a as a labeled reference strain. The high levels of homology of these strains to 1593 , the group IIA reference strain, leaves no doubt that they are in fact members of homology group IIA. In addition, the group IIA pathogens exhibited high levels of homology to Gt1-a.

Therefore, it appears that although all of the pathogens belong to homology group IIA, this homology group also contains nonpathogens. It is interesting that Jahnz et al. (3) recovered only nonpathogens when they used their probe. These authors suggested that the nonpathogens may, in fact, be more common in soil than the homology group IIA pathogens. Whether a pathogen or a nonpathogen is isolated may simply depend on the method used for selection (i.e., pathogenicity or response to the group IIA probe). In view of this, it does not seem appropriate to utilize mosquito pathogenicity as the sole characteristic for defining a new species based on homology group IIA.

\section{REFERENCES}

1. Aquino de Muro, M., and F. Priest. 1994. A colony hybridization procedure for the identification of mosquitocidal strains of Bacillus sphaericus on isolation plates. J. Invertebr. Pathol. 63:310-313.

2. Aquino de Muro, M., W. Mitchell, and F. Priest. 1992. Differentiation of mosquito-pathogenic strains of Bacillus sphaericus from non-toxic varieties by ribosomal RNA gene restriction patterns. J. Gen. Microbiol. 138:1159-1166.

3. Jahnz, U., A. Fitch, and F. Priest. 1996. Evaluation of an rRNA-targeted oligonucleotide probe for the detection of mosquitocidal strains of Bacillus sphaericus in soils; characterization of novel strains lacking toxin genes. FEMS Microbiol. Ecol. 20:91-99.

4. Johnson, J. L. 1994. Similarity analysis of DNAs, p. 655-682. In P. Gerhardt, R. G. E. Murray, W. A. Wood, and N. R. Krieg (ed.), Methods for general and molecular bacteriology. ASM Press, Washington, D.C.

5. Krych, V., J. Johnson, and A. Yousten. 1980. Deoxyribonucleic acid homologies among strains of Bacillus sphaericus. Int. J. Syst. Bacteriol. 30:476-484.

6. Liu, J.-W., A. Porter, B. Y. Wee, and T. Thanabalu. 1996. New gene from nine Bacillus sphaericus strains encoding highly conserved 35.8-kilodalton mosquitocidal toxins. Appl. Environ. Microbiol. 62:2174-2176.

7. Porter, A., E. Davidson, and J.-W. Liu. 1993. Mosquito toxins of bacilli and their genetic manipulation for effective biological control of mosquitoes. Microbiol. Rev. 57:838-861.

8. Thanabalu, T., and A. Porter. 1996. A Bacillus sphericus gene encoding a novel type of mosquitocidal toxin of $31.8 \mathrm{kDa}$. Gene 170:85-89.

9. Woodburn, M. A., A. Yousten, and K. Hilu. 1995. Random amplified polymorphic DNA fingerprinting of mosquito-pathogenic and nonpathogenic strains of Bacillus sphericus. Int. J. Syst. Bacteriol. 45:212-217. 